\title{
ANTIBACTERIAL, ANTIFUNGAL, ANTITUMOR AND TOXICITY OF ESSENTIAL OILS OF SALVIA OFFICINALIS, THYMUS VULGARIS, EUGENIA CARYOPHYLLATA AND ARTEMISIA ABSINTHIUM
}

\author{
E.A. Ewais ; Magda M. Aly ${ }^{* * * * *}$; M.A. Ismaill; E.H. Abdel Shakour ${ }^{*}$ and M.F. Hassanin ${ }^{*}$ \\ * Dept. Botany and Microbiology, Fac. Sci., Al-Azhar Univ., Cairo, Egypt. \\ ** Dept. Biology, Fac. Sci., King Abdulaziz Univ., Jeddah, Saudi Arabia. \\ *** Dept. Botany, Fac. Sci., Kafrelsheikh Univ., Egypt.
}

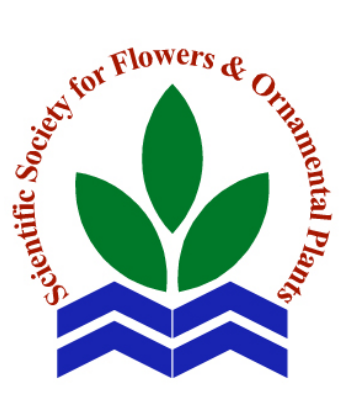

Scientific J. Flowers \& Ornamental Plants, 1(3):265-274 (2014).

Received:

9/11/2014

Revised by:

Prof. Dr. B.M. Refaat, Fac. Sci., Al-Azhar Univ

Prof. Dr. E.S. Nofal, Kafr El-Sheikh Univ.

\begin{abstract}
Essential oils are aromatic and volatile liquids extracted from plants. The chemicals in essential oils are secondary metabolites, which play an important role in plant defense as they often possess antimicrobial properties. In this study, essential oils of four plants were investigated for their antimicrobial activity against eight bacterial pathogens and seven fungal strains. The used plants were Salvia officinalis, Thymus vulgaris, Eugenia caryophyllata and Artemisia absinthium.

All of plants essential oils showed antibacterial and antifungal activities. Zones of inhibition against pathogenic bacteria ranged from 10 to $28 \mathrm{~mm}$ and MIC from 25 to $150 \mu \mathrm{g} / \mathrm{ml}$, while zones of inhibition against fungal strains ranged from 10 to $26 \mathrm{~mm}$ and MIC from 25 to $150 \mu \mathrm{g} / \mathrm{ml}$. Cytotoxicity against Artimia salina and antitumor activity against Ehrlich ascites carcinoma and Lymphoma cell line were investigated. A. absinthium showed the best antitumor activity on Lymphoma cell line with moderate cytotoxic effect on Artimia salina. Analysis of $A$. absinthium essential oil by GC-MS discovered two major compounds; camphor and fenchone which may be involved in the biological activity of the plant extract.
\end{abstract}

Key words: Salvia, Thymus, Eugenia, Artemisia, essential oil, GCMS.

\section{INTRODUCTION}

Antimicrobial chemotherapy has conferred huge benefits on human health. Many microorganisms that have acquired resistance to drugs through a variety of mechanisms have emerged and continue to plague human beings (Tomoo and Keizo, 2009). Because of the side effects and the resistance that pathogenic microorganisms build against antibiotics, recently much attention has been paid to extracts and biologically active compounds isolated from plant species used in herbal medicine (Essawi and Srour, 2000). Since ancient times, herbs and their essential oils have been known for their varying degrees of antimicrobial activity (Juven et al., 1994). The use of plant compounds to treat infection is an age-old practice in a large part of the world, especially in developing countries, where there is dependence on traditional medicine for a variety of diseases (Gangoue-pieboji et al., 2006). Traditional healers have long used plants to prevent or cure infectious conditions and plants are rich in a wide variety of secondary metabolites, such as tannins, terpenoids, alkaloids, and flavonoids, which have been found in vitro to have antimicrobial properties (Cowan, 1999). 


\section{E.E.A. Ewais et al.}

Sage (Salvia officinalis L., Lamiaceae) has antimicrobial potential (Bozin et al., 2007) and is used as a medicinal plant to treat dental diseases in Brazil (Oliveira et al., 2007). The antimicrobial activity may probably present because the essential oils are composed of several substances that can interact jointly in a synergic/potential form, giving them strong antimicrobial activity (Delamare et al., 2007 and Faleiro et al., 2003).

The genus Artemisia consists of small herbs and shrubs (Baytop et al., 1984 and Davis, 1982) and has much pharmaceutical interest (Baytop et al., 1984 and Kalemba et al., 2002). Artemisia species have been used in folk remedies as an antipyretic, antiseptic, antihelminitic, tonic, diuretic and for the treatment of stomach ache (Baytop et al., 1984).

Eugenia caryophyllata (clove) was found to be effective against egg and adult of Pediculus capitis (Yang et al., 2003). It has antiseptic as well as bacteriostatic and bactericidal activity against $E$. coli and $S$. aureus (Burt and Reinders, 2003 and Ernst, 2001). Growth of Helicobacter pylori being one of the major causes of peptic ulcer disease has been shown to be inhibited by $E$. caryophyllata (Bae et al., 1998). Several studies have demonstrated potent antifungal activity (Arina and Iqbal, 2002; Giordani et al., 2004; Pawar and Thaker, 2006 and Park et al., 2007), antiviral (Chaieb et al., 2007a) and antibacterial effects of clove (Cai and Wu, 1996; Lopez et al., 2005; Li et al., 2005 and Betoni et al., 2006).

The antimicrobial and fungicidal activities of Thymus vulgaris (thyme), were analyzed (Panizzi et al., 1993) against Gram negative and positive bacteria (Marino et al., 1999). Carvacrol was identified to be a predominant compound in thyme oil (Karaman et al., 2001). The composition of essential oils of some Thymus species was analyzed and in vitro antimicrobial activities of its components were reported and antibacterial activity of methanolic extract of
T. pubescense was detected (Azaz et al., 2004 and Mehrgan et al., 2008).

\section{MATERIALS AND METHODS}

\section{Plant materials:}

Aerial parts, fruits, roots or leaves of the plants were collected from local markets in Jeddah, Saudi Arabia during summer 2012. The collected plant materials were put in clean plastic bags and transferred directly to the lab. The plants under investigation were Salvia officinalis, Thymus vulgaris, Eugenia caryophyllata and Artemisia absinthium.

\section{Tested organisms:}

Bacterial and fungal isolates were obtained from Biology Department, Faculty of Science, King Abdul-Aziz University (KAU), Jeddah. The bacterial strains were Escherichia. coli ATCC 25922, Pseudomonas aeruginosa ATCC 27853, Klebsiella pneumoniae (ESBL) ATCC 700603, A. baumannii ATCC 1656-2, $P$. mirabilis ATCC 12453, Staphylococcus aureus ATCC 25923, Staphylococcus aureus (MRSA) ATCC 33591 and Enterococcus faecalis (VRE) ATCC 51299. The tested fungi were Aspergillus flavus, Aspergillus niger, Epidermophyton floccosum., Trycophyton mentagrophytes and Microsporum canis. Two strains of yeasts were investigated in this study; Candida albicans and Cryptococcus neoformans.

\section{Preparation of plant extracts:}

Dried powder of Salvia officinalis, Thymus vulgaris, Eugenia caryophyllata and Artemisia absinthium (100 g) was placed in soxhlet apparatus (Electromantle ME) with $450 \mathrm{ml}$ of methanol for $12 \mathrm{~h}$ at $90^{\circ} \mathrm{C}$. The extract was dried over sodium carbonate anhydro (BDH, England) and filtered through Whatman filter paper No.1. The organic solvents were evaporated under reduced pressure in a rotary evaporator. The produced oil was dissolved in dimethyl sulfoxide (DMSO) and kept in sealed dark glass bottles at low temperature $\left(4^{\circ} \mathrm{C}\right.$. $)$. 


\section{Antimicrobial Activity:}

This test was carried out using agar well diffusion method according to Joshi et al. (2009). Bacteria or yeast were taken and shaken in the sterile distilled water corresponding to $10^{8} \mathrm{CFU} / \mathrm{ml}$ for bacteria and $10^{6} \mathrm{CFU} / \mathrm{ml}$ for yeast (Mihajilov-Krstev et al., 2010). Fungal inocula were prepared by flooding Petri dish with 8 to $10 \mathrm{ml}$ of distilled water and the conidia were scraped using sterile spatula. The spore density of each fungus was $1.5 \times 10^{4}$ spore $/ \mathrm{ml}$ (Adigüzel et al., 2005). Minimal inhibitory concentration (MIC) was determined by the method recommended by Ter-Laak et al. (1991). Each antimicrobial agent was serially diluted by transferring $100 \mu \mathrm{l}$ of the antimicrobial agent through sterilized microtitre plate containing $100 \mu \mathrm{l}$ media (nutrient broth for bacteria, Sabouraud dextrose broth for fungi and yeast). Freshly prepared standard number of cells $\left(1.5 \times 10^{8}\right.$ $\mathrm{CFU} / \mathrm{ml}$ for bacteria or yeast and $4 \times 10^{4}$ spore/ml for fungal isolates) was added to the media that contained some drops of phenol red. Glucose metabolisms were measured by a change of the color of phenol red indicator from red to yellow. MIC was determined at the concentration with no color change and DMSO were used as a control.

Toxicity and antitumor activity of the plant extracts:

Cytotoxicity is performed by Brine Shrimp Test (BST). Different dilutions of each plant extract made in DMSO were prepared $(100,200,300$ and $400 \mu \mathrm{g} / \mathrm{ml})$ and $0.5 \mathrm{ml}$ of each dilution was added to $4.5 \mathrm{ml}$ of brine solution and maintained at room temperature for $24 \mathrm{~h}$ under the light (Krishnaraju et al., 2005). The surviving larvae were counted by light microscope and the number of dead shrimp in each vial was recorded. The concentration at which $50 \%$ of the larvae were killed $\left(\mathrm{LD}_{50}\right)$ was determined as the toxic concentration (Lachumy et al., 2010). The antitumor activity of the tested plants was determined against Ehrlich carcinoma and Lymphoma cell line. Cells were grown in RPMI 1640 medium (Sigma, USA) with $10 \%$ fetal calf serum (FCS) (Gibco, USA) at $37^{\circ} \mathrm{C}$ under a humidified atmosphere consisting of $95 \%$ air and $5 \%$ $\mathrm{CO}_{2}$ for $48 \mathrm{~h}$. The percentage of cell viability was assessed to determine the 50\% lethal dose by which $50 \%$ of cells are killed $\left(\mathrm{LD}_{50}\right)$.

\section{Chemical analysis of the crude extracts by GC-MS:}

The compounds and structures of major components were analyzed by GC-MS (Perkin Elmer).

\section{RESULTS AND DISCUSSION}

Antimicrobial activity of the essential oils of $S$. officinalis, $T$. vulgaris, $E$. caryophyllata and $A$. absinthium was investigated against some Gram positive bacteria, Gram negative bacteria, yeast and filamentous fungi. Table (1) and (2) are showing the effect of plant essential oils on pathogenic bacteria.

All of plant essential oils showed antibacterial activity. The inhibition zones are variable according to the type of the plant. E. caryophyllata and $S$. officinalis recorded the same maximum inhibition against $K$. pneumonia. The former showed also the highest inhibition zone against $P$. mirabilis, while the latter showed the highest zone against Methicillin Resistant $S$. aureus 33591. For all other bacteria, A. absinthium exhibited the largest inhibition zones than other plants essential oils ranging from 17 $\mathrm{mm}$. to $28 \mathrm{~mm}$. MIC values were $50-150$ $\mu \mathrm{g} / \mathrm{ml}$. However, the moderate activity against $P$. mirabilis and the slight decreasing in the inhibition zones against $K$. pneumonia and MRSA than $S$. officinalis did not exclude A. absinthium essential oil as the strongest against most of bacterial strains in this study. In this respect, Sengul et al. (2011) obtained broad spectrum antimicrobial activity of $A$. absinthium methanolic extract against many Gram positive and Gram negative bacteria. Also, Erel et al. (2012) reported antimicrobial activity of $A$. absinthium essential oil against E. coli, S. aureus and $E$. 
E.E.A. Ewais et al.

Table 1. Antimicrobial activity of essential oils using agar well diffusion method against bacterial pathogens.

\begin{tabular}{|c|c|c|c|c|c|}
\hline Bacteria & $\begin{array}{c}\text { Salvia } \\
\text { officinalis }\end{array}$ & $\begin{array}{c}\text { Artemisia } \\
\text { absinthium }\end{array}$ & $\begin{array}{c}\text { Eugenia } \\
\text { caryophyllata }\end{array}$ & $\begin{array}{l}\text { Thymus } \\
\text { vulgaris }\end{array}$ & Control \\
\hline P. aerugenosa & $16.7 \pm 1.5$ & 28.00 & $18.6 \pm 8.1$ & $18.6 \pm 8.1$ & ND \\
\hline K. pneumoniae & $26 \pm 1.1$ & 24.00 & $26 \pm 0.0$ & $16 \pm 0.0$ & ND \\
\hline P. mirabilis & $17.7 \pm 1.0$ & 17.00 & $26.7 \pm 5.8$ & $16.7 \pm 1.8$ & ND \\
\hline A. baumannii & $19 \pm 0.5$ & 28.00 & $11 \pm 1.7$ & $13 \pm 1.2$ & ND \\
\hline E. faecalis & $24 \pm 1.4$ & 28.00 & $14 \pm 2.0$ & $18 \pm 1.0$ & ND \\
\hline S. aureus 33591 & $21.7 \pm 1.32$ & 20.00 & $16.7 \pm 0.5$ & $12.7 \pm 0.15$ & ND \\
\hline S. aureus 25923 & $10 \pm 8.7$ & 24.00 & 15 & 16 & ND \\
\hline E. coli & $21 \pm 1.7$ & 27.00 & $18.3 \pm 7.7$ & $18.3 \pm 1.0$ & ND \\
\hline Bacterial Index ${ }^{*}$ & 155.4 & 196 & 145.7 & 129.3 & ND \\
\hline
\end{tabular}

* Bacterial Index: Total Activity (mm).

Table 2. The minimal inhibitory concentrations $(\mu \mathrm{g} / \mathrm{ml})$ of essential oils against bacterial pathogens.

\begin{tabular}{|c|c|c|c|c|c|}
\hline Bacteria $\quad$ Plants & $\begin{array}{c}\text { Salvia } \\
\text { officinalis }\end{array}$ & $\begin{array}{c}\text { Artemisia } \\
\text { absinthium }\end{array}$ & $\begin{array}{c}\text { Eugenia } \\
\text { caryophyllata }\end{array}$ & $\begin{array}{l}\text { Thymus } \\
\text { vulgaris }\end{array}$ & Control \\
\hline$\overline{P . \text { aerugenosa }}$ & 50 & 50 & 25 & 150 & $>200$ \\
\hline K. pneumoniae & 100 & 50 & 50 & 50 & $>200$ \\
\hline P. mirabilis & 50 & 50 & 25 & 150 & $>200$ \\
\hline A. baumannii & 50 & 50 & 50 & 50 & $>200$ \\
\hline E. faecalis & 50 & 100 & 100 & 100 & $>200$ \\
\hline S. aureus 33591 & 50 & 150 & 25 & 100 & $>200$ \\
\hline S. aureus 25923 & 100 & 100 & 50 & 150 & $>200$ \\
\hline E. coli & 150 & 150 & 25 & 100 & $>200$ \\
\hline
\end{tabular}

faecalis. Zanousi et al. (2012) reported antimicrobial activity of $A$. absinthium against E. coli, K. pneumonia, E. faecalis and $S$. aureus. They found that the most effective essential oil of the plant has been extracted from fruits, but there was no antimicrobial activity against $P$. aeruginosa has been detected. T. vulgaris oil has the weakest antimicrobial activity against bacterial isolates. Inhibition zone diameter range was $12.7-18.6 \mathrm{~mm}$.

The effect of plant essential oils on yeast and filamentous fungi is represented in Table (3) and (4). The effect of essential oils on the tested fungi has also revealed that the strongest activity was recorded for $A$. absinthium with considerable increasing in inhibition zones. Zone diameter range was 13-25 $\mathrm{mm}$. and MIC was $50-100 \mu \mathrm{g} / \mathrm{ml}$.
Similarly, Taherkhani et al. (2013) found that the leaf essential oil of $A$. absinthium indicated significant activity against $C$. albicans. Also, Juteau et al. (2003) recorded the similar result. Only three strains are different in their susceptibility response. One of them is $T$. mentagrophytes, since it was more susceptible to the essential oil of $E$. caryophyllata. Others were A. flavus and $M$. canis. They were affected by the oil of $T$. vulgaris with the largest inhibition zone of 21 and $23 \mathrm{~mm}$, respectively and MIC 100, 25 $\mu \mathrm{g} / \mathrm{ml}$, in that order.

Cytotoxicity and antitumor activity of the plants essential oils are shown in Table (5). Investigation of antitumor activity of plant essential oils showed that $A$. absinthium was the third active essential oil against Lymphoma cell line and Erlich cell 
Table 3. Antimicrobial activity of essential oils using agar well diffusion method against selected pathogenic yeasts and fungi.

\begin{tabular}{|c|c|c|c|c|c|}
\hline $\begin{array}{ll}\text { Fungi } & \text { Plants } \\
\end{array}$ & $\begin{array}{c}\text { Salvia } \\
\text { officinalis }\end{array}$ & $\begin{array}{c}\text { Artemisia } \\
\text { absinthium }\end{array}$ & $\begin{array}{c}\text { Eugenia } \\
\text { caryophyllata }\end{array}$ & $\begin{array}{l}\text { Thymus } \\
\text { vulgaris }\end{array}$ & Control \\
\hline A. flavus & $19 \pm 1.3$ & $16 \pm 0.23$ & $17 \pm 1.00$ & $23 \pm 1.0$ & ND \\
\hline A. niger & $19+0.18$ & $21+.08$ & $19.8 \pm 1.4$ & $20+0.15$ & ND \\
\hline E. floccosum & $14 \pm 1.0$ & $24 \pm 0.22$ & $19 \pm 1.0$ & $21 \pm 0.18$ & ND \\
\hline T. mentagrophytes & $17 \pm 1.0$ & $13 \pm 0.03$ & $19 \pm 0.90$ & $11 \pm 1.0$ & ND \\
\hline M. canis & $18 \pm 0.10$ & $19 \pm 0.14$ & $18 \pm 1.00$ & $21 \pm 0.18$ & ND \\
\hline C. albicans & $18 \pm 0.11$ & $26 \pm 0.16$ & $18 \pm 0.10$ & $10 \pm 0.15$ & ND \\
\hline C. neoformans & $19 \pm 0.18$ & $25 \pm 0.01$ & $19 \pm 0.17$ & $17 \pm 2.16$ & ND \\
\hline Fungal index ${ }^{*}$ & 140 & 165 & 147.8 & 140 & ND \\
\hline
\end{tabular}

* Fungal Index: Total Activity (mm).

Table 4. The minimal inhibitory concentration $(\mu \mathrm{g} / \mathrm{ml})$ of essential oils against pathogenic fungi

\begin{tabular}{|c|c|c|c|c|c|}
\hline Fungi Plants & $\begin{array}{c}\text { Salvia } \\
\text { officinalis }\end{array}$ & $\begin{array}{c}\text { Artemisia } \\
\text { absinthium }\end{array}$ & $\begin{array}{c}\text { Eugenia } \\
\text { caryophyllata }\end{array}$ & $\begin{array}{l}\text { Thymus } \\
\text { vulgaris }\end{array}$ & Control \\
\hline A. flavus & 150 & 100 & 100 & 25 & $>200$ \\
\hline A. niger & 150 & 100 & 100 & 50 & $>200$ \\
\hline E. floccosum & 150 & 100 & 100 & 50 & $>200$ \\
\hline T. mentagrophytes & 150 & 100 & 50 & 50 & $>200$ \\
\hline M. canis & 150 & 100 & 100 & 100 & $>200$ \\
\hline C. albicans & 100 & 50 & 100 & 50 & $>200$ \\
\hline C. neoformans & 100 & 50 & 100 & 50 & $>200$ \\
\hline
\end{tabular}

Table 5. Toxicity against Artimia salina and antitumor activities of the different concentrations of selected plant essential oils (EOs).

\begin{tabular}{lccc}
\hline \multirow{2}{*}{ Plants } & $\begin{array}{c}\text { Toxicity against } \text { Artimia } \\
\text { salina }\end{array}$ & \multicolumn{2}{c}{ ADtitumor activity $\left(\mathbf{L D}_{\mathbf{5 0}} \boldsymbol{\mu g} \mathbf{\mu g} / \mathbf{m l}\right)$} \\
\cline { 3 - 4 } & 600 & Lymphoma cell line & Erlich cell line \\
\hline Salvia officinalis & 400 & 400 & 400 \\
Artemisia absinthium & 600 & 600 & 400 \\
Eugenia caryophyllata & $\geq 600$ & 200 & 400 \\
Thymus vulgaris & & $\geq 600$ & $\geq 600$ \\
\hline
\end{tabular}




\section{E.E.A. Ewais et al.}

line. The highest active essential oil was $E$. caryophyllata, while $T$. vulgaris has no antitumor activity. In accordance, Jeong Seo (2003) reported that the artemisetin isolated from Afsantin (Artemisia absinthium Linn.) exhibited marked antitumor activity against melanoma. Taherkhani (2014) also confirmed that the essential oil displayed good cytotoxic action towards the human tumor cell line. Toxicity against Artimia salina has been studied, the highest cytotoxic effect was recorded for the essential oil of $A$. absinthium ( $\left.\mathrm{LD}_{50} 400\right)$. However this value means a moderate cytotoxic effect. Taherkhani (2014) reported that cytotoxicity of the oil towards human tumor cell line is much higher than that required for healthy human cells. These results indicate low adverse effects for the oil. Lust (1979) reported that pure $A$. absinthium (wormwood) oil is very poisonous, but with proper dosage, it has little or no danger.

The essential oil of $A$. absinthium was investigated by GC-MS to identify active compounds. Two major compounds were identified, the first one was bicyclo[2.2.1]heptan-2-one, 1,3,3-trimethyl; common name (fenchone) and the second compound is bicyclo[2.2.1] heptan-2-one, 1,7,7-trimethyl; common name (camphor). Mass spectra for both compounds are shown in Figures (1) and (2). Fenchone is suggested to be involved in the antimicrobial activity of activity of Foeniculum vulgare is attributed to fenchone present in its essential oil (Dinesh et al., 2014). In contrast, fenchone was not considered a potent antimicrobial agent as mentioned by Lis-Balchin and Roth (2000). The second compound may also be contributed to the antimicrobial activity of $A$. absinthium is bicyclo[2.2.1] heptan-2-one, 1,7,7-trimethyl; common name (camphor). Nibret and Wink (2010) recorded that $A$. absinthium essential oil contains $3.7 \%$ camphor. Guvenalp et al. (1998), reported that camphor is one of the main components of the essential oils of some Artemisia species. According to Mukul (2013), camphor and davanone are the major components of $A$. absinthium essential oil. Nibret and Wink (2009) also reported that $A$. absinthium oil containing $38.37 \%$ camphor. Camphor is hypothesized to contribute to the antimicrobial activity of $A$. absinthium oil. This is agreed with Mahboubi and Kazempour (2009), they investigated the antimicrobial activity of camphor against Gram positive bacteria, Gram negative bacteria, yeast and filamentous fungi. Camphor is known to be toxic when ingested in large amounts, and may lead to seizures, confusion, irritability and neuromuscular hyperactivity (Liebelt and Shannon, 1993 and Ryno, 2009). Thus the cytotoxic effect of A. absinthium essential oil may be attributed to its camphor content.

A. absinthium. Similarly, antibacterial

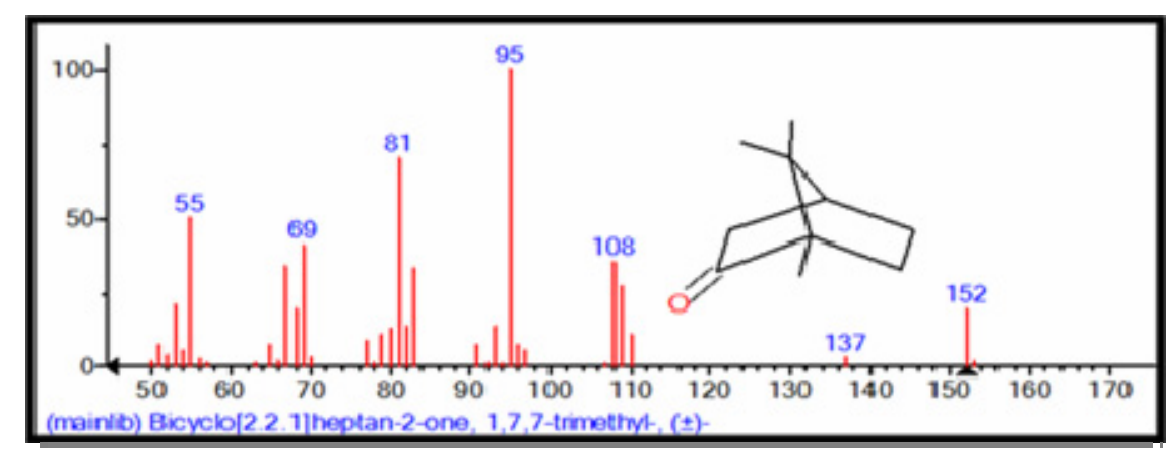

Fig. 1. Mass spectrum of bicyclo [2.2.1] heptan-2-one, 1,7,7trimethyl, $( \pm)$. 


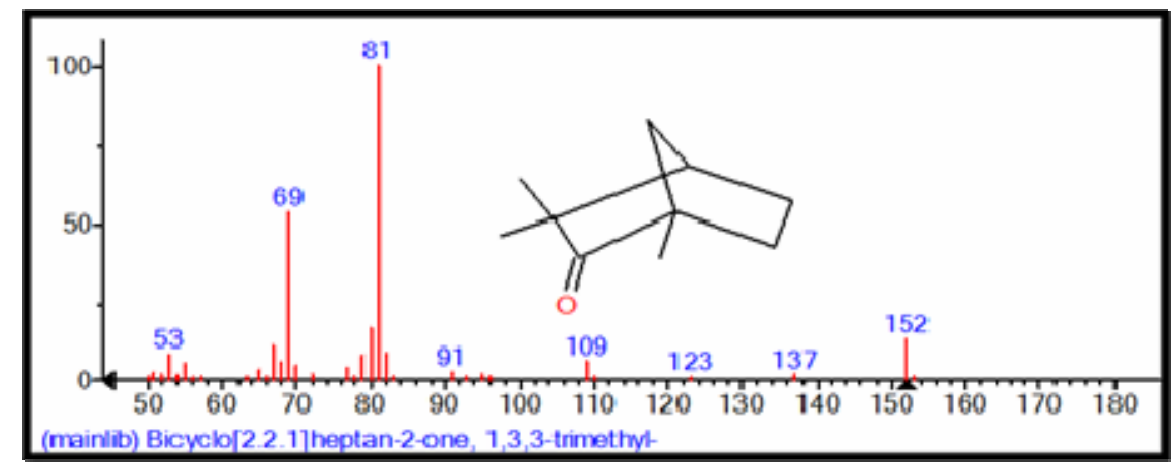

Fig. 2. Mass spectrum of bicyclo [2.2.1]heptan-2-one, 1,3,3trimethyl', $( \pm)$.

\section{CONCLUSION}

Our results pointed out the potential value of $A$. absinthium essential oil against some bacterial and fungal isolates, as it exhibits the strongest antimicrobial activity among all of the tested plant essential oils with moderate cytotoxic effect and antitumor activity. Fenchone and/or Camphor are the major compounds may contribute to the biological activities of the plant essential oil.

\section{REFERENCES}

Adigüzel, A.; Güllüce, M.; Şenqül, M.; Öğ̈̈tcü, H.; Şahian, F. and Karaman, I. (2005). Antimicrobial effects of Ocimum basilicum (Labiatae) extract, Turkish J. Biotechnol., 29:155-160.

Arina, B. and Iqbal, A. (2002). In vitro fungitoxicity of the essential oil of Syzygium aromaticum. World J. Mocrobiol. Biotech., 18(4):317-319.

Azaz, A.D.; Huseyin, A.; Irtem, H.A.; Lu, M.K. and Baser, K.H.C. (2004). Composition and the in vitro Antimicrobial activities of the essential oils of some Thymus species. Z. Naturforsch., 59(1-2):75-80.

Bae, E.A.; Han, M.J.; Kim, N.J. and Kim, D.H. (1998). Anti-Helicobacter pylori activity of herbal medicines. Biol. Pharm. Bull., 21(9):990-992.

Baytop, T. (1984). Türkiye'de Bitkiler ile Tedavi. I.U. Yayinlari No: 3255, Eczacilik Fak. No: 40 Ýstanbul, 444 pp.
Betoni, J.E.; Mantovani R.P; Barbosa, L.N.; De-Stasi, L.C. and Junior, F.A. (2006). Synergism between plant extract and antimicrobial drugs used on Staphylococcus diseases. Mem. Inst. Oswaldo Cruz., 101(4):387-390.

Bozin, B.; Mlmica-Dukic, N.; Samojlik, I. and Jovin, E. (2007). Antimicrobial and antioxidant properties of rosemary and sage (Rosmarinus officinalis L. and Salvia officinalis L., Lamiaceae) essential oils. J. Agric. Food. Chem., 55:78797885 .

Burt, S.A. and Reinders, R.D. (2003). Antibacterial activity of selected plant essential oils against Escherichia coli O157:H7. Lett. Appl. Microbiol., 36(3):162-167.

Cai, L. and Wu, C.D. (1996). Compounds from Syzygium aromaticum possessing growth inhibitory activity against oral pathogens. J. Nat. Prod., 59(10):987-990.

Chaieb, K.; Hajlaoui, H.; Zmantar, T.; Nakbi, K.A.B.; Rouabhia, M.; Mahdouani, K. and Bakhrouf, A.. (2007a). The chemical composition and biological activity of essential oil, Eugenia cryophyllata (Syzygium aromaticum L. Myrtaceae): a short review. Phytother. Res., 21(6):501-506.

Cowan, M.M. (1999). Plant Products as Antimicrobial Agents, Clin. Microbiol. 12(4):564-582. 


\section{E.E.A. Ewais et al.}

Davis, P.H. (1982). Flora of Turkey and the East Aegean Islands. Edinburgh University Press, Scotland, 311 pp.

Delamare, A.P.L.; Moschen-Pistorello, I.T.; Artico, L.; Atti-Serafini, L. and Echeverrigaray, S., (2007). Antibacterial activity of the essential oils of Salvia officinalis L. and Salvia triloba L. cultivated in South Brazil. Food Chem., 100:603-608.

Dinesh, S.B.; Menon, K.R.K. and Manish, K.S. (2014). Comparative antimicrobial activity of essential oils of Cuminum cyminum L. and Foeniculum vulgare Mill. seeds against Salmonella typhimurium and Escherichia coli. Journal of Essential Oil Bearing Plants, 17(4):617-622.

Erel, Ş.; Reznicek, G.; Şenol, S.G.; Karabay Yavaşoğulu N.U.; Konyalioğlu, S. and Zeybek, A.U. (2012). Antimicrobial and antioxidant properties of Artemisia L. species from western Anatolia. Turk J. Biol., 36:75-84.

Ernst, E. (2001). The Desktop Guide to Complementary and Alternative Medicine. China. Mosby, 576 pp.

Essawi, T., Srour, M. (2000). Screening of some Palestinian medicinal plants for antibacterial activity. J. Ethnopharmacol., 70:343-349.

Faleiro, M.L.; Miguel, M.G.; Ladeiro, F.; Venancio, F.; Tavares, R.; Brito, J.C.; Figueiredo, A.C.; Barroso, J.G. and Pedro, L.G. (2003). Antimicrobial activity of essential oils isolated from Portuguese endemic species of Thymus. Lett. Appl. Microbiol., 36(1):35-40.

Gangoue-pieboji, J.; Pegnyemb, D.E. and Niyitegeka, D. (2006). The in-Vitro antimicrobial activities of some medicinal plants from Cameroon. Annals of Tropical Medicine and Parasitology, 100(3):273- 243.

Giordani, R.; Regli, P.; Kaloustian, J.; Mikail, C.; Abou, L. and Portugal, $\mathrm{H}$. (2004). Antifungal effects of various oils against Candida albicans. Potentiation of antifungal action of amphotericin B by essential oil from Thymus vulgaris. Phytother. Res., 18(12):990-995.

Guvenalp, Z.; Cakir, A.; Harmandar, M. and Gleispach, H. (1998). The essential oil of Artemisia austriaca Jacq. and Artemisia spicigera C. Koch from Turkey. Flavour Fragrance J., 13:26-28.

Jeong, S. (2003). Antitumour activity of flavonoids isolated from Artemisia. Plant Medicine, 69(3):218-222.

Joshi, B.; Lekhak, S. and Sharma, A. (2009). Antibacterial Property of Different Medicinal Plants: Ocimum sanctum, Cinnamomum zeylanicum, Xanthoxylum armatum and Origanum majorana. Journal of Science, Engineering and Technolgy,5 (I):143- 150.

Juteau, F.; Jerkovic, I.; Masotti, V.; Milos, M.; Mastelic, J.; Bessiere, J.M. and Viano, J. (2003). Composition and antimicrobial activity of the essential oil of Artemisia absinthium from Croatia and France. Planta Med., 69:158-161.

Juven, B.J.; Kanner, J.; Schved, F.; and Weisslowicz, H. (1994). Factors that interact with the antibacterial action of thyme essential oil and its active constituents. J. Appl. Bacteriol., 76:626631.

Kalemba, D.; Kusewicz, D. and Swiader, K. (2002). Antimicrobial properties of the essential oil of Artemisia asiatica Nakai. Phytother. Res., 16:288-291.

Karaman, S.; Digrak, M. and Ravid, V. (2001). Antibacterial and antifungal activity of the essential oils of Thymus revolutus from Turkey. J. Ethanopharamacol., 76(2):183-186.

Krishnaraju, A.V.; Rao, T.V.N.; Sundararaju, D.; Vanisree, M.; Tsay, H. and Subbaraju, G.V. (2005). Assessment of bioactivity of indian medicinal plants using brine shrimp (Artemia salina) lethality assay. International Journal of 
Applied Science and Engineering., 3(2):125-134.

Lachumy, S.J.; Zuraini, Z. and Sasidharan, S. (2010). Antimicrobial activity and toxicity of methanol extract of Cassia fistula seeds. Research Journal of Pharmaceutical, Biological and Chemical Sciences., 1(4):391- 398.

Li, Y.; Xu, C.; Zhang, Q.; Liu, J.Y. and Tan, R.X. (2005). In vitro anti-Helicobacter pylori action of 30 Chinese herbal medicines used to treat ulcer diseases. J. Ethnopharmacol., 98(6):329-333.

Liebelt, E.L. and Shannon, M.W. (1993). Small doses, big problems: A selected review of highly toxic common medications. Pediatr. Emerg. Care, 19:292-297.

Lis-Balchin, M. and Roth, G. (2000). Composition of the essential oils of Pelargonium odoratissimum, $P$. exstipulatum, and $P . \quad x$ fragrans (Geraniaceae) and their bioactivity. Flav. Fragr. J., 15:391-394.

Lopez, P.; Sanchez, C.; Batlle, R. and Nerin, C. (2005). Solid- and Vapor-phase antimicrobial activities of six essential oils: susceptibility of selected food borne bacterial and fungal strains. J. Agric. Food Chem., 53(17): 6939-6946.

Lust, J.N.D. (1979). The Herb Book. Bantam Books, 659 pp.

Mahboubi, M. and Kazempour, N. (2009). The antimicrobial activity of essential oil from Perovskia abrotanoides karel and its main components. Indian J. Pharm. Sci.,71:343-347.

Marino, M.; Bersani, C. and Comi, G. (1999). Antimicrobial activity of the essential oils of Thymus vulgaris L. measured using a biopediometric method. J. Food Protection., 62:10-17.

Mehrgan, H.; Mojab, F.; Pakdaman, S. and Poursaeed, M. (2008). Antibacterial activity of Thymus pubescens methanolic extract. Iranian J. Pharm. Res., 7(4): 291295.

Mihajilov-Krstev, T.; Radnović, D. and Kitić, D. (2010). Antimicrobial activity of Satureja L. essential oils against phytopathogenic bacteria Erwinia amylovora. Biologica Nyssana., 1(1-2): 95-98.

Mukul, C. (2013). Chemical investigations of the essential oils of some Artemisia species of Ethiopia. IOSR Journal of Applied Chemistry, 6(4):1-7.

Nibret, E. and Wink, M. (2009). Volatile components of four Ethiopian Artemisia species extracts and their in vitro antitrypanosomal and cytotoxic activities. Phytomedicine, 17(5):369-74.

Nibret, E. and Wink, M. (2010). Volatile components of four Ethiopian Artemisia species extracts and their in vitro antitrypanosomal and cytotoxic activities. Phytomedicine, 17:369-374.

Oliveira, F.Q.; Gobira, B.; Guimarães, C.; Batista, J.; Barreto, M. and Souza, M. (2007). Espécies vegetais indicadas na odontologia. Rev. Bras. Farmacogn, 17:466-476.

Panizzi, L.; Flamini, G.; Lioni, P.L. and Morelly, I. (1993). Composition and antimicrobial properties of essential oils of four mediterranean lamiaceae. J. Ethanopharmacol., 39(3):167-70.

Park, M.J.; Gwak, K.S.; Yang, I.; Choi, W.S.; Jo, H.J.; Chang, W.J.; Jeung, E.B. and Choi, I.G. (2007). Antifungal activities of the essential oils in Syzygium aromaticum (L.) Merr. Et Perry and Leptospermum betersonni Bailey and their constituents against various dermatiphytes. J. Microbiol., 45(5):460465 .

Pawar, V.C. and Thaker, V.S. (2006). In vitro efficacy of oils against Aspergillus niger. Mycosis, 49(4):316-323.

Ryno, F. (2009). An Investigation into The Antimicrobial and Anticancer Activities of Geranium incanum, Artemisia afra 


\section{E.E.A. Ewais et al.}

and Artemisia absinthium. M.Sc. Thesis, Faculty of Health Science, Nelson Mandela Metropolitan University, p. 27.

Sengul, M.; Ercisli, S.; Hilal, Y.; Neva, G.; Arzu, K. and Bülent, Ç. (2011). Antioxidant, antimicrobial activity and total phenolic content within the aerial parts of Artemisia absinthum, Artemisia santonicum and Saponaria officinalis. Iranian Journal of Pharmaceutical Research, 10(1):49-56.

Taherkhani, M.; Rustaiyan, A.; Rasooli, I. and Taherkhani, T. (2013). Chemical composition, antimicrobial activity, antioxidant and total phenolic content within the leaves essential oil of Artemisia absinthium L. growing wild in Iran. African Journal of Pharmacy and Pharmacology., 7(2):30-36.

Taherkhani, M. (2014). In vitro cytotoxic activity of the essential oil extracted from Artemisia absinthium. Iranian Journal of Toxicology, 8(26):1152-1156.

Ter-Laak, E.A.; Pijpers, A.; Noordergraaf, J.H.; Schoevers, E.C. and Verheijden,
J.H. (1991). Comparison of methods for in vitro testing of susceptibility of porcine Mycoplasma species to antimicrobial agents. Antimicrob Agents Chemother, 35:228-233.

Tomoo, S. and Keizo, Y. (2009). History of antimicrobial agents and resistant bacteria. JMAJ, 52(2):103-108.

Yang, Y.C.; Lee, S.H.; Lee, W.J.; Choi, D.H. and Ahn, Y.J. (2003). Ovicidal and adulticidal effects of Eugenia caryophyllata bud and leaf oil compounds on Pediculus capitis. J. Agric. Food Chem., 51(17):4884-4888.

Zanousi, M.B.; Azar, P.A. and Raeesi, M. (2012). Chemical composition and antimicrobial activity of essential oils of different organs of three Artemisia species from Iran. Journal of Medicinal Plants Research, 6(42):5489-5494.

\footnotetext{
التأثير المضاد للبكتريا و الفطريات و الأورام وسمية الزيوت الطيارة لنباتات المريمية والزعتر والقرنقل والشيح

عماد الدين عباس عويس"، ماجدة محمد على "******، محمد عبد الحمبد إسماعيل"، عصام حسين عبد الثكور "، محمد فر غلى حسنين"

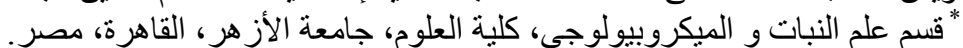

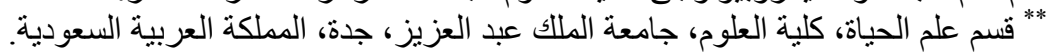

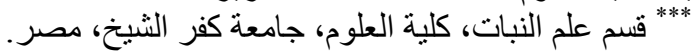

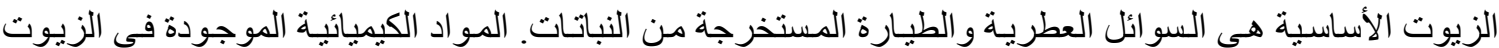

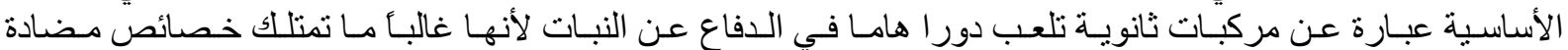

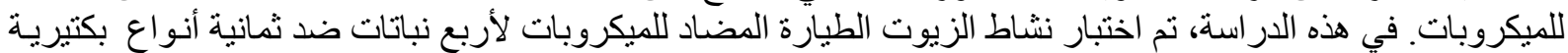

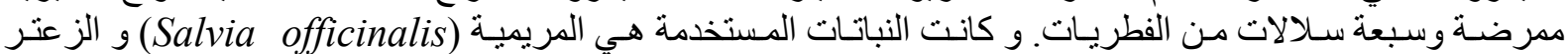
(Eugenia caryophyllata) و و الشيح (Thymus vulgaris)

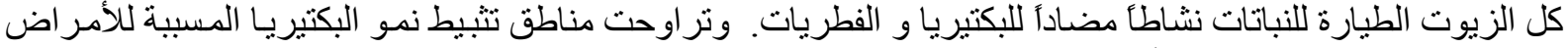

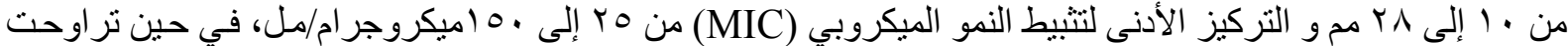

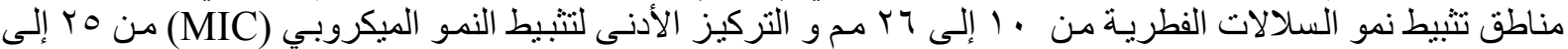

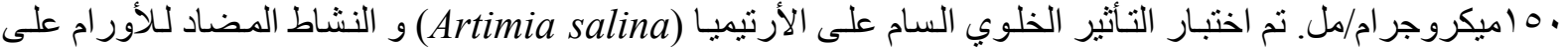

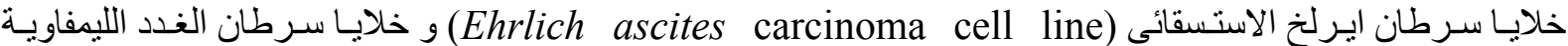
(Lymphoma cell line)

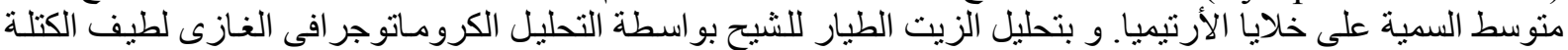

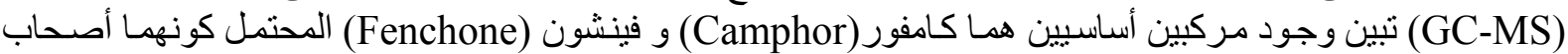
الدور الرئيسي في النشاط الحيوي للزيت الطيار للنبات.
} 